\title{
Localization of a High-Molecular-Weight Actin Binding Protein in the Sea Urchin Egg from Fertilization through Cleavage
}

\author{
Tomoyoshi Yoshigaki ${ }^{1}$, Shohei Maekawa, Sachiko Endo, and Hikoichi \\ Sakai \\ Department of Biophysics and Biochemistry, Faculty of Science, University of \\ Tokyo, Hongo, Tokyo 113, Japan
}

\begin{abstract}
Immunoblotting analysis demonstrated that the 260-kDa actin-binding protein ( $260 \mathrm{~K}$ protein) isolated from fertilized eggs of sea urchin, Hemicentrotus pulcherrimus, is immunologically different from mammalian fodrin (brain spectrin) and filamin. Rotary shadowing analysis revealed that the $260 \mathrm{~K}$ protein is a flexible molecule measuring about $100 \mathrm{~nm}$ in length, which further indicated that it does not belong to the family of "spectrins". The isolated cortex was doubly stained with affinity-purified anti-260K protein antibody and rhodamine-labeled phalloidin to localize the $260 \mathrm{~K}$ protein in comparison with the distribution of microfilaments. In unfertilized eggs and fertilized eggs at various developmental stages, the fluorescence for actin corresponded closely to the immunofluorescence for the $260 \mathrm{~K}$ protein. In the unfertilized egg, the $260 \mathrm{~K}$ protein showed a spotty distribution superimposed on the distribution of actin. The $260 \mathrm{~K}$ protein was localized in the fertilization cone and the elongated microvilli which are composed of a microfilament bundle. A marked accumulation of the $260 \mathrm{~K}$ protein was observed in the cleavage furrow. Immunoelectron microscopy using the secondary antibody labeled with colloidal gold particles indicated that the $260 \mathrm{~K}$ protein is localized exclusively in the cell periphery beneath the plasma membrane. A high density of gold particles was detected along fibrous structures in many protrusions which seemed to correspond to microvilli. These observations suggested that the $260 \mathrm{~K}$ protein is involved in the cortical cytoskeleton composed mainly of microfilament.
\end{abstract}

The cortex of animal eggs undergoes dynamic morphological changes in fertilization and during early development (34). The formation of the fertilization cone, the elongation of microvilli and the constriction of the cleavage furrow are the main cellular events which occur in the cortex of the sea urchin egg. These structural changes are known to emerge based on the reorganization of cortical cytoskeletons which are mainly composed of microfilaments $(26,30)$.

Previous observations suggest that actin-regulatory factors are involved in the morphological changes of the cortex. Besides myosin (16) and tropomyosin (9), various actin-binding proteins have been purified from sea urchin eggs and characterized: depolymerizing factors $(5,17)$, severing factors $(7,35)$, capping pro-

\footnotetext{
1 To whom reprint request should be addressed
} 
tein (6) and cross-linking factors $(11,18)$.

Recently, a spectrin-like protein was isolated from sea urchin eggs and characterized $(3,13)$. Spectrin is widely distributed as an important component of the membrane skeleton (1), so sea urchin spectrin is expected to play an important role in the dynamic changes of the cortex in sea urchin eggs.

In the previous study (21), we isolated an actin-binding protein having a molecular weight of 260,000 from the cortex fraction of fertilized eggs of the sea urchin, Hemicentrotus pulcherrimus. This protein (260K protein) has properties to bind to polymerized actin and to induce the formation of actin bundles in vitro. Immunoblotting analysis demonstrated that the $260 \mathrm{~K}$ protein was predominantly present in the cortex fraction. It was suggested that the $260 \mathrm{~K}$ protein is associated with microfilaments and involved in the cortical cytoskeleton.

This paper deals with the comparison of the $260 \mathrm{~K}$ protein with mammalian filamin and fodrin (brain spectrin), the distribution of the $260 \mathrm{~K}$ protein in the sea urchin egg cortex from fertilization through the first cleavage, and its ultrastructural localization.

\section{MATERIALS AND METHODS}

Immunostaining of the isolated cortex. Gametes from the sea urchin Hemicentrotus pulcherrimus kept in an aquarium with Jamalin $\mathrm{V}$ were obtained by intracoelomic injection of $0.5 \mathrm{M} \mathrm{KCl}$. The eggs were washed several times in artificial sea water $(485 \mathrm{mM} \mathrm{NaCl}$, $10 \mathrm{mM} \mathrm{KCl}, 27 \mathrm{mM} \mathrm{MgCl} 2 \cdot 6 \mathrm{H}_{2} \mathrm{O}, 29 \mathrm{mM} \mathrm{MgSO} 4 \cdot 7 \mathrm{H}_{2} \mathrm{O}, 2.4 \mathrm{mM} \mathrm{NaHCO}, 10 \mathrm{mM} \mathrm{CaCl}_{2}$, pH 8.2 adjusted with $1 \mathrm{M} \mathrm{Na}_{2} \mathrm{CO}_{3}$ solution). After insemination, the egg suspension was combined with $10 \mathrm{vol}$. of $1 \mathrm{M}$ urea and passed through a nylon mesh $(70 \mu \mathrm{m})$. The eggs were washed several times and cultured in a $\mathrm{Ca}^{2+}$-free artificial sea water $\left(\mathrm{CaCl}_{2}\right.$ was omitted from the above solution). The isolation of the cortex was performed according to the method of Spudich and Spudich (28) with some modifications. A small volume of the egg suspension was put on poly-L-lysine-coated coverslips and the eggs were settled. Adhered eggs were lysed by squirting a stream of the cortex isolation medium $(0.1 \mathrm{M} 2$-( $\mathrm{N}$-morpholino) ethanesulfonic acid (MES)-KOH, $10 \mathrm{mM}$ ethylene-glycol bis (2-amino-ethylether)-N, N, N', N'tetraacetic acid (EGTA), $10 \mathrm{mM}$ p-tosyl-L-arginine methylester (TAME), $1 \mathrm{mM} \mathrm{MgCl}$, pH 6.8, with $1 \%$ Triton $\mathrm{X}-100$ ). The cortical layers retained on the coverslip were fixed immediately with $3.7 \%$ formaldehyde in PBS (20 mM potassium phosphate- $\mathrm{KOH}, 140 \mathrm{mM}$ $\mathrm{NaCl}, \mathrm{pH} 7.4$ ) for $5 \mathrm{~min}$ and washed twice in PBS. PBS containing $0.5 \%$ BSA and $0.01 \%$ goat IgG was applied to the isolated cortices for $1 \mathrm{~h}$ in a moist chamber. The specimens were incubated with the primary antibody, affinity-purified anti-260K protein antibody (dilution 1:3), mixed with rohdamine-labeled phalloidin (Molecular Probe, Inc.) (dilution 1:20) for $1 \mathrm{~h}$ in a moist chamber. The specimens were washed several times in PBS and incubated with the secondary antibody, FITC-goat anti-rabbit IgG (Cappel) diluted 1:100 for $1 \mathrm{hr}$, followed by several washes in PBS. The coverslips were then immersed briefly in double-distilled water and mounted on glass slides in $80 \%$ glycerol in PBS. Control stainings were performed using the secondary antibody alone. The specimens were observed under a Nikon MICROPHOTFX microscope with an epifluorescence system and photographed on Kodak Tri-X film. The films were developed in Pandol. All procedures described above were performed at room temperature.

Immunogold staining method. The cortices of eggs which mostly reached the metaphase of the first division were isolated on an Epon-Araldite plate as described above. Electron microscope analysis of the cortex using the secondary antibody coupled to $15 \mathrm{~nm}$ gold par- 
ticles was performed according to the method of Langanger et al. (15). The cortices were fixed with $0.5 \%$ glutaraldehyde in solution A (10 mM MES, $2 \mathrm{mM} \mathrm{MgCl}_{2}, 0.2 \mathrm{mM}$ EGTA, $100 \mathrm{mM} \mathrm{NaCl}, \mathrm{pH} 6.7$ ) for $10 \mathrm{~min}$. They were washed in solution $A$ and immersed in $1 \mathrm{mg} / \mathrm{ml}$ sodium borohydride in solution A for $20 \mathrm{~min}$. The specimen was incubated and washed in solution B [20 mM tris (hydroxymethyl) aminomethane (Tris) $\mathrm{HCl}, 140 \mathrm{mM} \mathrm{NaCl}$, pH 8.2] $+0.1 \%$ BSA. PBS containing $0.5 \%$ BSA was applied to the cortices. They were incubated with the first antibody, affinity-purified anti-260K protein antibody (21) diluted 1:3, followed by rinses in PBS. The specimen was incubated overnight with the secondary antibody, goat anti-rabbit IgG coupled to $15 \mathrm{~nm}$ gold particles (E.Y LABS, INC.) diluted 1:4 with solution B containing $0.1 \%$ BSA. The control sample was incubated with the secondary antibody alone. The specimen was washed in solution $\mathrm{B}$ containing $0.1 \% \mathrm{BSA}$ and then washed in solution $\mathrm{C}$ (sodium phosphate buffer, $72 \mathrm{mM} \mathrm{Na}_{2} \mathrm{HPO}_{4}$ and $28 \mathrm{mM} \mathrm{NaH}_{2} \mathrm{PO}_{4}, \mathrm{pH}$ 7.4). The cortices were postfixed with $1 \%$ glutaraldehyde and $0.2 \%$ tannic acid in solution $\mathrm{C}$ for $60 \mathrm{~min}$, followed by rinses in the same solution. They were further postfixed with $0.5 \% \mathrm{OsO}_{4}$ in solution $\mathrm{C}$ for $10 \mathrm{~min}$ on ice, and washed in solution $\mathrm{C}$ and then in DDW. The specimen was stained with $1 \%$ uranyl acetate and $1 \%$ phosphotungstic acid in $70 \%$ ethanol and infiltrated in a 1:1 mixture of absolute ethanol and Epon-Araldite for $60 \mathrm{~min}$. It was then embedded in Epon-Araldite, sectioned and viewed with a Hitachi H-7000 electron microscope. All procedures described above were performed at room temperature, unless otherwise stated.

Immunoblotting analysis. Purified 260K protein was prepared as described by Maekawa et al. (21). Porcine brain spectrin (fodrin) was purified as reported previously (8) and bovine stomach muscle filamin was purified according to the method of Feramisco and Burridge (2). The three proteins were electrophoresed in separate wells according to the method of Laemmli (14). After electrophoresis, proteins were transferred onto nitrocellulose sheets according to the method of Towbin et al. (31) at $4^{\circ} \mathrm{C}$ for $6 \mathrm{~h}$ in the presence of $0.1 \%$ SDS. Four nitrocellulose sheets, each of which retained the three proteins, were prepared. One of the nitrocellulose sheets was stained for 5 min with $0.1 \%$ amidoblack dissolved in $5 \%$ methanol and $10 \%$ acetic acid and destained briefly with $40 \%$ methanol and $10 \%$ acetic acid. The others were incubated with $3 \%$ gelatin in TBS $(20 \mathrm{mM}$ Tris- $\mathrm{HCl}, 0.5 \mathrm{M} \mathrm{NaCl}, \mathrm{pH} \mathrm{7.4})$ for $1 \mathrm{~h}$ at $37^{\circ} \mathrm{C}$. Each sheet was probed with either affinity-purified anti-260K protein antibody, antiserum against porcine brain spectrin (fodrin) or affinity-purified anti-filamin antibody. The sheets were washed three times in TBS containing $0.05 \%$ Tween 20 for $30 \mathrm{~min}$ and incubated for $2 \mathrm{~h}$ at $37^{\circ} \mathrm{C}$ with horseradish peroxidase-conjugated goat anti-rabbit IgG or anti-mouse IgG (Cappel) diluted 1:1000 in TBS containing 1\% gelatin. The sheets were then washed as described above and immersed in $0.05 \%$ 4-chloro-1-naphthol and $0.01 \% \mathrm{H}_{2} \mathrm{O}_{2}$ in TBS. The enzyme reaction was stopped by rinsing in $\mathrm{H}_{2} \mathrm{O}$ and the sheets were immediately photographed.

Antibodies. Anti-260K protein antibody was prepared and affinity-purified as described previously (21). Anti-filamin antibody was prepared as follows. Purified bovine stomach muscle filamin was electrophoresed in the presence of SDS and the corresponding bands were excised after the gels were stained with coomassie brilliant blue. After washing several times in PBS, the dissected bands were homogenized in the presence of Freund's complete (for the first injections) or incomplete adjuvant (for following injections). Ten mice were immunized by four series of injections and the collected serum was affinity-purified as described previously (21). Anti-fodrin antiserum was obtained in our laboratory using two rabbits and was used without further purification.

Other methods. Purified $260 \mathrm{~K}$ protein was examined by the low-angle rotary shadowing technique of Tyler and Branton (32). The contour length of the individual molecules was 
measured from random survey micrographs printed at a magnification of 202,500.

\section{RESULTS}

Characterization of the $260 \mathrm{~K}$ protein. Immunoblotting analysis was performed to examine the immunological cross-reactivity of the $260 \mathrm{~K}$ protein to well-known high molecular weight actin binding proteins, bovine stomach muscle filamin and porcine brain spectrin (fodrin). Polyclonal antibody raised against the $260 \mathrm{~K}$ protein reacted with neither filamin nor fodrin (Fig. 1B). The $260 \mathrm{~K}$ protein did not react with the polyclonal antibody raised against filamin or antiserum raised against fodrin (Figs. 1C, D). These results indicated that the $260 \mathrm{~K}$ protein is immunologically different from mammalian filamin and fodrin.

The $260 \mathrm{~K}$ protein viewed by rotary shadowing exhibited various shapes (Fig. 2), which suggests that the $260 \mathrm{~K}$ protein is a flexible molecule. The molecules seemed to be composed of a single chain measuring $106 \pm 19 \mathrm{~nm}(\mathrm{n}=96)$ in length. However, the $260 \mathrm{~K}$ protein sometimes looked as if the molecule was composed of more than two chains. This image may suggest the possibility that the protein aggregates into oligomer in vivo. The SDS-PAGE showed that the purified $260 \mathrm{~K}$ protein fraction us-

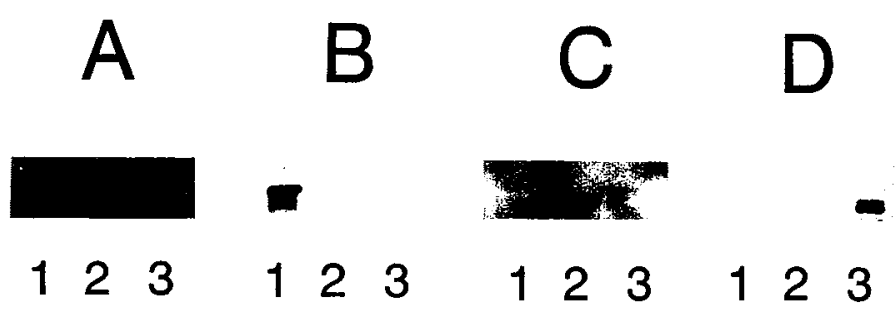

Fig. 1. Immunological dissimilarity between the $260 \mathrm{~K}$ protein, filamin, and fodrin. The $260 \mathrm{~K}$ protein (lane 1), bovine stomach muscle filamin (lane 2), and porcine brain fodrin (lane 3) were electrophoretically separated by SDS-PAGE $(6 \%)$ and transferred to nitrocellulose. The nitrocellulose strips were stained with amidoblack (A) and immunostained with affinity-purified anti-260K protein antibody (B), affinity-purified anti-filamin antibody (C), and antiserum raised against fodrin (D) (see MateRIALS AND METHODs). Each antibody cross-reacted with only the corresponding protein. Note a single band of purified $260 \mathrm{~K}$ protein in contrast to two separated bands of fodrin. Only the high-molecular-weight portion of the blot is shown.
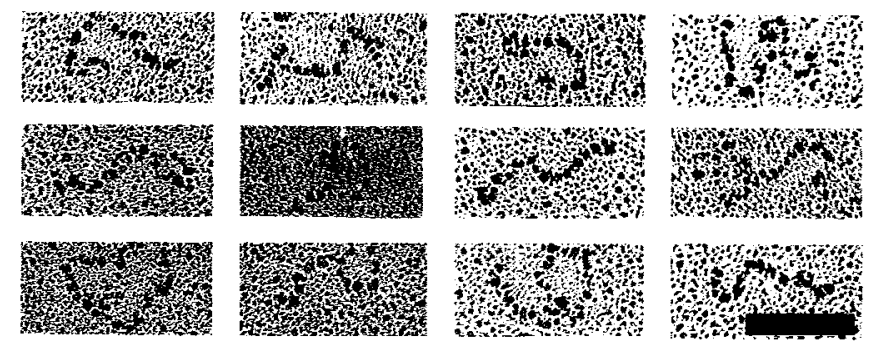

Fig. 2. Low-angle rotary shadowed images of the $260 \mathrm{~K}$ protein. The average length of the molecules was $106 \pm 19 \mathrm{~nm}(\mathrm{n}=96)$ by quantitative analysis of the contour length of the $260 \mathrm{~K}$ protein. Bar $=50 \mathrm{~nm}$. 
ed for the rotary shadowing analysis was quite homogeneous.

Double staining of the isolated cortex. To localize microfilaments and the $260 \mathrm{~K}$ protein in the isolated cortex, double staining was performed using rhodamine-labeled phalloidin which stained polymerized actin and affinity-purified anti-260K protein antibody.

In unfertilized eggs, polymerized actin showed a spotty distribution over the entire cortex. The fluorescence image of the $260 \mathrm{~K}$ protein corresponded to that of actin (Figs. 3a, b). Soon after fertilization, a bright spot of fluorescence for actin, which was thought to be a fertilization cone, was often observed (Fig. 4a). In staining the isolated cortex with DAPI which localizes chromosomes, sperm heads were sometimes observed within the bright spot. Most fertilization cones, however, lost these sperm heads during the isolation process. The same bright spot was observed in the corresponding fluorescence image of the $260 \mathrm{~K}$ protein (Fig. $4 \mathrm{~b}$ ). After fertilization, numerous needle-like fluorescence areas appeared in the cortex stained
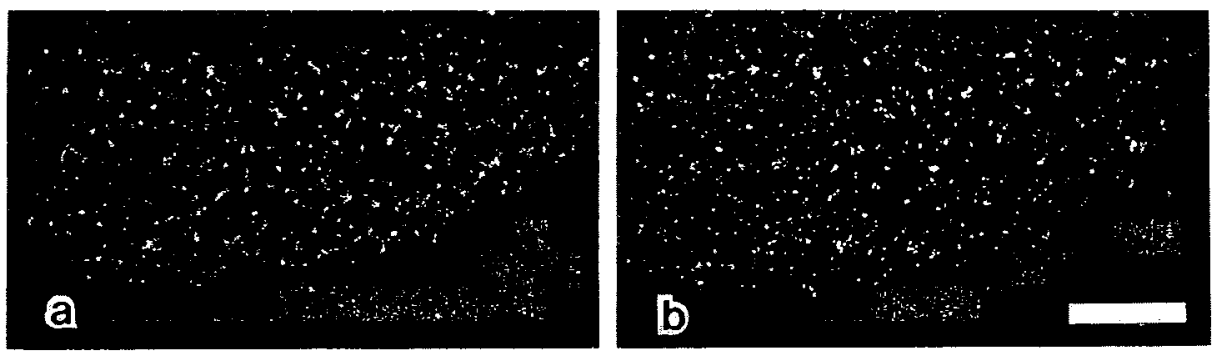

Fig. 3. Fluorescence micrographs of the isolated cortex of an unfertilized egg. Spotty fluorescence images for actin (a) and immunofluorescence for the $260 \mathrm{~K}$ protein (b) are detected in the same cortex. Only a portion of the whole isolated cortex is shown. Bar $=10 \mu \mathrm{m}$.
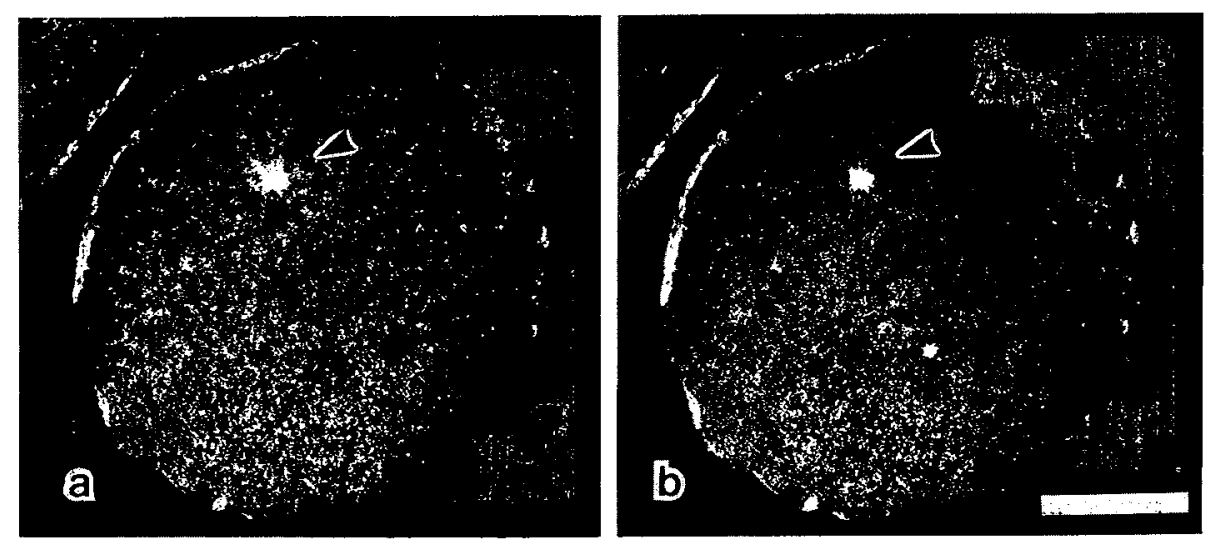

Fig. 4. Fluorescence micrographs of cortices isolated soon after insemination. A cortex stained for actin (a) and for the $260 \mathrm{~K}$ protein (b) is shown. Bar $=50 \mu \mathrm{m}$. A bright spot of fluorescence which corresponds to a fertilization cone is observed (see arrowheads). The other smaller spot in (b) seems to be an aggregate of the secondary antibody. 

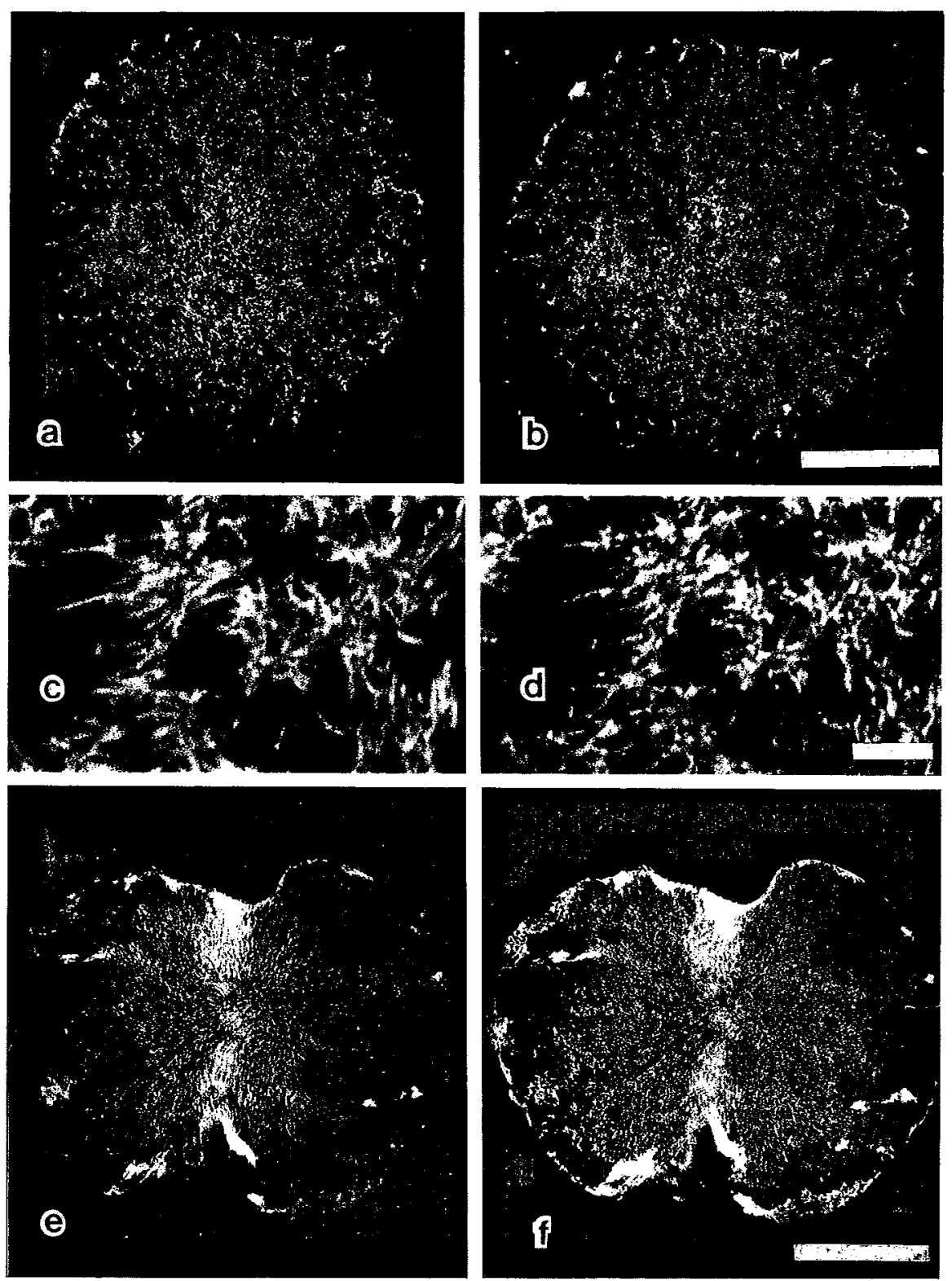

Fig. 5. Fluorescence micrographs of cortices isolated $25 \mathrm{~min}$ after insemination. A cortex stained for actin (a) and for the $260 \mathrm{~K}$ protein (b) is shown. Bar $=50 \mu \mathrm{m}$. A portion of another cortex isolated $25 \mathrm{~min}$ after fertilization is shown at a higher magnification ( $c$ and $d)$. Numerous needle-like images which correspond to microvilli are observed in both the fluorescence stainings for actin (c) and the $260 \mathrm{~K}$ protein (d). $\mathrm{Bar}=5 \mu \mathrm{m}$. The fluorescence images of the telophase cortex stained for actin (e) and the $260 \mathrm{~K}$ protein (f). Both actin and the $260 \mathrm{~K}$ protein are concentrated in the cleavage furrow region. Bar $=50 \mu \mathrm{m}$. 

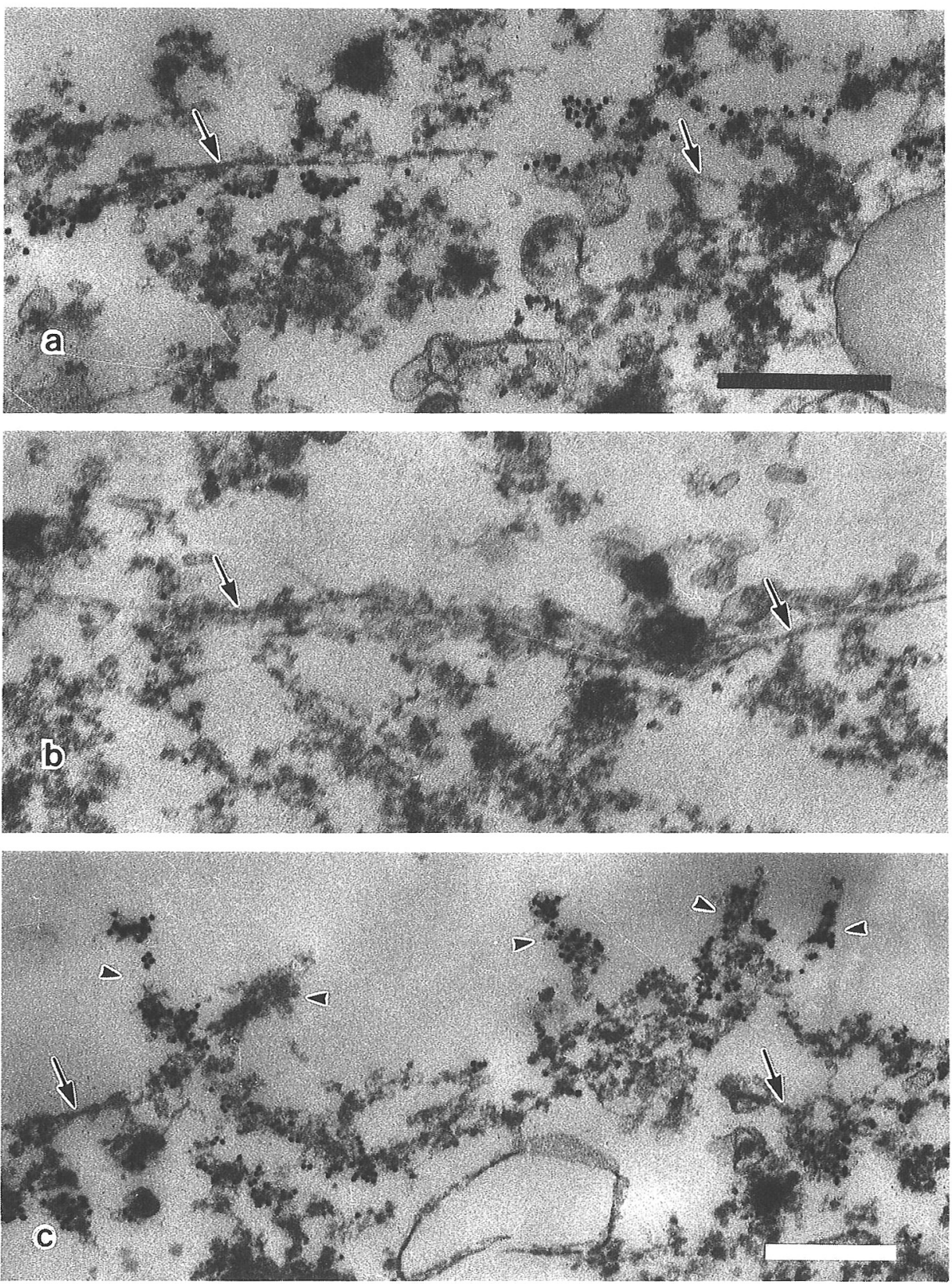

Fig. 6. Immunoelectron microscopy of cortices isolated at metaphase to localize the $260 \mathrm{~K}$ protein (see Materials AND Methods). A high density of gold particles is restricted to the cell periphery (a). In the control specimen (b), gold particles are scarcely detected. In (c), several protrusions with concentrated gold particles are shown. Bar: $0.5 \mu \mathrm{m}(\mathrm{a}, \mathrm{b}), 0.5 \mu \mathrm{m}$ (c). Arrowheads show microvillous protrusions and arrows the plasma membrane. 
with rhodamine-labeled phalloidin (Fig. 5c). This fluorescence pattern was thought to correspond to microvilli that possess a core of bundles of microfilaments. The localization of the $260 \mathrm{~K}$ protein was identical to that of actin (Fig. 5d).

A bright belt-like fluorescence for actin was observed in the cleavage furrow region of the cortex in the telophase (Fig. 5e). This fluorescence seemed to correspond to the actin filaments of the contractile ring because the size of the belt-like region corresponded closely to that of the contractile ring previously described (26). The fluorescence image of the $260 \mathrm{~K}$ protein was very similar to that of actin filaments (Fig. 5f).

The above results obtained by double staining of the isolated cortex demonstrated that the $260 \mathrm{~K}$ protein is localized in the cortex of unfertilized eggs, the fertilization cone, the microvilli and the cleavage furrow and that there were no marked differences in distribution patterns between the actin fluorescence and the $260 \mathrm{~K}$ protein immunofluorescence in the cortex from fertilization through the first cleavage (Figs. 5a, b).

Immunoelectron microscopy. Immunoelectron microscopy using the secondary antibody coupled to $15 \mathrm{~nm}$ gold particles demonstrated that the localization of the $260 \mathrm{~K}$ protein is restricted to the egg surface (Fig. 6a). Gold particles were concentrated at the cell periphery beneath the plasma membrane and were scarcely detected away from the plasma membrane. A few gold particles were detected in the control specimen (Fig. 6b).

In electron micrographs, numerous protrusions, which were thought to be microvilli, were observed. Many gold particles were localized in these protrusions
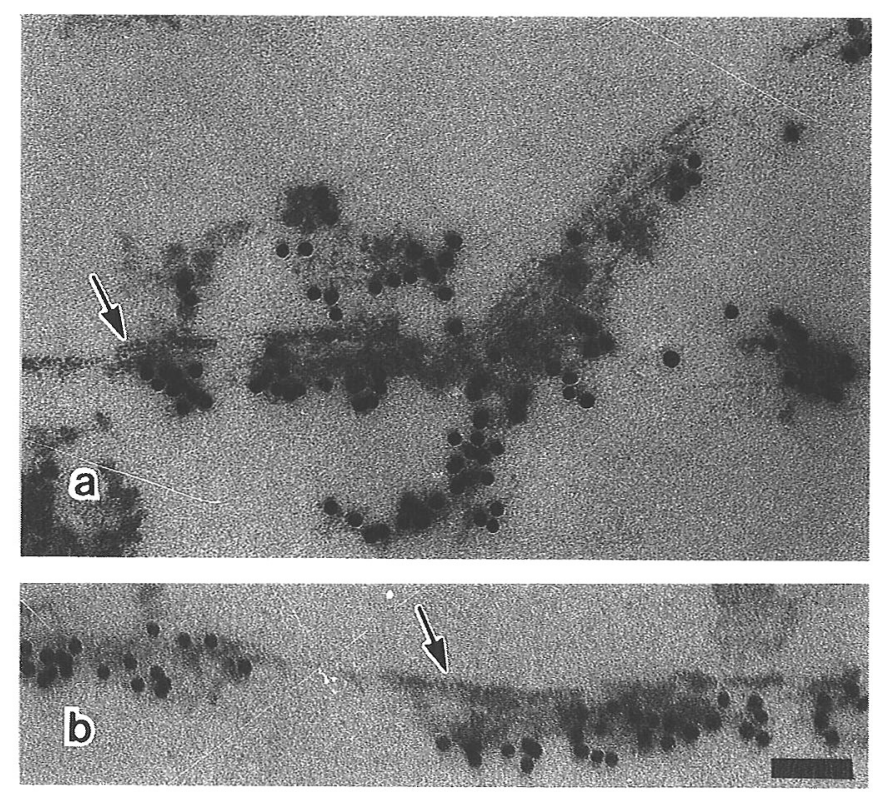

Fig. 7. A higher magnification view of a protrusion is shown in (a), where filaments were preserved and gold particles were preferentially localized around the structure possibly corresponding to the microvillous rootlet. Localization of gold particles underneath the plasma membrane is shown in (b) at a higher magnification. Bar $=0.1 \mu \mathrm{m}$. Arrows show the plasma membrane. 
(Figs. 6a, c). Figure 6c shows several protrusions mostly covered with gold particles. A protrusion at higher magnification is shown in Fig. 7a where the preserved fibrous structure inside the protrusion seems to represent an actin bundle. A high density of gold particles was especially localized around the rootlet of the protrusion. Besides the protrusions, gold particles were shown to be localized beneath the plasma membrane (Fig. 7b). Most of the gold particles were not attached directly to the membrane but were associated with some amorphous materials.

\section{DISCUSSION}

Spectrin-like protein, which shares an immunologically detectable homology with chicken erythrocyte spectrin, was isolated from sea urchin eggs and characterized $(3,13)$. The rotary shadowing analysis showed that sea urchin spectrin was a rodshaped molecule measuring either $100 \mathrm{~nm}$ or $200 \mathrm{~nm}$ in length, which corresponds to the dimer or to the tetramer, respectively. On the other hand, the $260 \mathrm{~K}$ protein showed a variety of morphologies (Fig. 2), which may indicate that the $260 \mathrm{~K}$ protein is a flexible molecule. Though the average length of the $260 \mathrm{~K}$ protein is close to that of the dimer of sea urchin spectrin, the difference in morphology in the rotary shadowing suggests that the $260 \mathrm{~K}$ protein is different from sea urchin spectrin.

Schatten et al. (25) presented evidence that a fodrin-like protein which crossreacted with antibody specific for the $a$-subunit of guinea pig brain fodrin was detected in sea urchin gametes and zygotes. This protein was shown to be localized in the acrosomal region of the sea urchin sperm. In contrast, the $260 \mathrm{~K}$ protein was not detected in that region (data not shown). Furthermore, they found no marked accumulation of the fodrin-like protein in the region of the cleavage furrow. These observations indicate that the $260 \mathrm{~K}$ protein does not belong to the family of protein species collectively referred to as "spectrins".

The $260 \mathrm{~K}$ protein was immunologically different from mammalian filamin (Fig. 1). Tropomyosin inhibits the interaction between filamin and actin filaments (23). On the other hand, the association of the $260 \mathrm{~K}$ protein with actin filaments is not inhibited by tropomyosin (22). These observations suggest that the $260 \mathrm{~K}$ protein is different from filamins which has already been reported.

Recently, an actin-binding protein which has a molecular weight of 250,000 was isolated from the soluble fraction of the egg of Hawaiian sea urchin, Tripneustes gratilla (19). It was reported that this protein cross-reacted weakly with the antibody against chicken gizzard filamin. Rotary shadowed images of the 250-kDa protein showed a wavy molecule $120-170 \mathrm{~nm}$ long, having some globular domains. In morphology and length, the $260 \mathrm{~K}$ protein was markedly different from the $250-\mathrm{kDa}$ protein. However, the rotary shadowed image of the $260 \mathrm{~K}$ protein was similar to filamin (33), so further study is necessary in order to clarify the relationship between the $260 \mathrm{~K}$ protein and the sea urchin filamin, if it exists.

In unfertilized eggs, the fluorescence of the $260 \mathrm{~K}$ protein corresponded to the spotty distribution of the polymerized actin (Fig. 3). This spotty pattern of actin, which corresponds to the stubby microvilli of unfertilized eggs, has been observed in some other sea urchins $(4,29,36)$. Recently, ultrastructural studies revealed that the microvilli of unfertilized eggs consist of a loose network of short microfilaments $(4,29)$. The distribution of the $260 \mathrm{~K}$ protein (Fig. $3 \mathrm{~b}$ ) shows that the protein may be involved in the construction of the loose network of microfilaments and further suggests that the protein does not work as an actin-bundling factor in the living cell, 
even though the $260 \mathrm{~K}$ protein causes actin filaments to bundle in vitro.

Fascin detected in the elongated microvilli of fertilized sea urchin eggs (24) has been considered to cross-link microfilaments to one another in the microvillar core, because this protein has the ability to induce bundling of actin filaments in vitro (12, 20). It was shown that fascin is not localized in stubby microvilli of unfertilized egg cortices (24). This observation suggests that fascin links one microfilament to another to form a tightly packed microfilament bundle as the core of the elongated microvilli. In contrast, the $260 \mathrm{~K}$ protein was shown to be localized in every actinbased structure, such as the stubby microvilli of unfertilized eggs (Fig. 3b), the fertilization cone (Fig. 4b), the elongated microvilli of fertilized eggs (Fig. 5d) and the contractile ring (Fig. 5f) superimposed on the distribution of actin. This observation indicates that the $260 \mathrm{~K}$ protein is always associated with actin-based cytoskeletons possibly functioning differently from that of fascin.

Figures $6 \mathrm{c}$ and $7 \mathrm{a}$ show that the $260 \mathrm{~K}$ protein is localized in the elongated microvilli at the ultrastructural level. Linear arrays of gold particles may indicate that the protein is associated with microfilaments in vivo. However, the $260 \mathrm{~K}$ protein generally remained in the isolated cortices from which most of actin had been extracted, and only a solution of high salt solubilized the $260 \mathrm{~K}$ protein (21). This extraction behavior and the localization in various actin-based structures in the vicinity of membranes lead to the idea that the $260 \mathrm{~K}$ protein links microfilaments to cortical insoluble materials attached to the plasma membrane.

In the contractile ring, microfilaments are parallel to one another and spaced 15 to $20 \mathrm{~nm}$ apart (26). Myosin (27) and tropomyosin (10) are enriched in the cleavage furrow region of the sea urchin egg, which favours the hypothesis that the constriction of the cleavage furrow occurs via the sliding of actin filaments. A marked accumulation of the $260 \mathrm{~K}$ protein in the furrow region (Fig. $5 \mathrm{f}$ ) shows that the protein is a component of the microfilament system in the contractile ring. It was shown that the association of the $260 \mathrm{~K}$ protein with actin filaments is not inhibited by tropomyosin from sea urchin eggs (22). This seems to be consistent with the idea that the $260 \mathrm{~K}$ protein plays a role in the construction of actin cytoskeletons in the contractile ring.

Acknowledgements. We thank Dr. Toshihiro Kitamoto for the rotary shadowing analysis. This work was supported by Grant-in-Aid from the Ministry of Education, Science, and Culture of Japan (60065005).

\section{REFERENCES}

1. Bennett, V. The membrane skeleton of human erythrocytes and its implications for more complex cells. Ann. Rev. Biochem. 54, 273-304, 1985

2. Feramisco, J.R. and K. Burridge. A rapid purification of $a$-actinin, filamin, and a 130,000 dalton protein from smooth muscle. J. Biol. Chem. 255, 1194-1199, 1980

3. FishKind, D.J., E.M. Bonder and D.A. BEGG. Isolation and characterization of sea urchin egg spectrin: Calcium modulation of the spectrin-actin interaction. Cell Motil. Cytoskel. 7, 304-314, 1987

4. Henson, J.H. and D.A. BegG. Filamentous actin organization in the unfertilized sea urchin egg cortex. Develop. Biol. 127, 338-348, 1988

5. Hosoya, H., I. Mabuchi and H. Sakai. Actin modulating proteins in the sea urchin egg. I. Analysis of G-actin-binding proteins by DNase I-affinity chromatography and purification of a 17,000 molecular weight component. J. Biochem. 92. 1853-1862, 1982

6. Hosoya, H. and I. MABUCHI. A 45,000-mol-wt protein-actin complex from unfertilized sea 
urchin egg affects assembly properties of actin. J. Cell Biol. 99, 994-1001, 1984

7. Hosoya, H., I. Mabuchi and H. SAKai. An 100-KDa Ca ${ }^{2+}$-sensitive actin-fragmenting protein from unfertilized sea urchin egg. Eur. J. Biochem. 154, 233-239, 1986

8. Ishikawa, M., H. Murofushi and H. Sakai. Bundling of microtubules in vitro by fodrin. $J$. Biochem. 94, 1209-1217, 1983

9. IsHIMODA-TAKAGI, T. Immunological purification of sea urchin egg tropomyosin. J. Biochem. 83, 1757-1762, 1978

10. Ishimoda-TAKAGI, T. Localization of tropomyosin in sea urchin eggs. Exp. Cell Res. 119, 423-428, 1979

11. KANE, R.E. Preparation and purification of polymerized actin from sea urchin egg extracts. $J$. Cell Biol. 66, 305-315, 1975

12. KANE, R.E. Actin polymerization and interaction with other proteins in temperature-induced gelation of sea urchin egg extracts. J. Cell Biol. 71, 704-714, 1976

13. Kuramochi, K., I. Mabuchi and K. Owaribe. Spectrin from sea urchin eggs. Biomed. Res. 7, 65-68, 1986

14. LAEMMLI, U.K. Cleavage of structural proteins during the assembly of the head of bacteriophage T4. Nature 227, 680-685, 1970

15. Langanger, G., J. DeMey, M. Moeremans, G. Daneels, M. DeBrabander and J.V. Small. Ultrastructural localization of $a$-actinin and filamin in culutured cells with the immunogold staining (IGS) method. J. Cell Biol. 99, 1324-1334, 1984

16. MabuChI, I. A myosin-like protein in the cortical layer of the sea urchin egg. J. Cell Biol. 59, $542-547,1973$

17. Mabuchi, I., and H. Hosoya. Actin-modulating proteins in the sea urchin egg. II. Sea urchin egg profilin. Biomed. Res. 3, 465-476, 1982

18. Mabuchi, I., Y. Hamaguchi, T. Kobayashi, H. Hosoya, S. Tsukita and S. Tsukita. Alpha-actinin from sea urchin eggs: Biochemical properties, interaction with actin, and distribution in the cell during fertilization and cleavage. J. Cell Biol. 100, 375-383, 1985

19. MabUChI, I. and R.E. KANE. A 250K-molecular-weight actin-binding protein from actin-based gels formed in sea urchin egg cytoplasmic extract. J. Biochem. 102, 947-956, 1987

20. Maekawa, S., S. Endo and H. Sakai. A protein in starfish sperm head which bundles actin filaments in vitro: Purification and characterization. J. Biochem. 92, 1959-1972, 1982

21. Maekawa, S., S. Endo and H. SaKaI. A high molecular weight actin binding protein: Its localization in the cortex of the sea urchin egg. Exp. Cell Res. 172, 340-353, 1987

22. Maekawa, S., M. Toriyama and H. Sakai. Tropomyosin in the sea urchin egg cortex. Eur. J. Biochem. 178, 657-662, 1989

23. Maruyama, K. and K. Ohashi. Tropomyosin inhibits the interaction of F-actin and filamin. $J$. Biochem. 84, 1017-1019, 1978

24. Otto, J.J., R.E. KANE and J. BRYAN. Redistribution of actin and fascin in sea urchin eggs after fertilization. Cell Motil. 1, 31-40, 1980

25. Schatten, H., R. Cheney, R. Balcon, M. Willard, C. Cline, C. Simerly and G. Schatten. Localization of fodrin during fertilization and early development of sea urchins and mice. Develop. Biol. 118, 457-466, 1986

26. SChroeder, T.E. Dynamics of the contractile ring. in Molecules and Cell Movement, ed. Inoue', S. and R.E. Stephens, Raven Press, New York. pp. 305-334, 1975

27. SCHROEDER, T.E. Fourth cleavage of sea urchin blastomeres: Microtubule patterns and myosin localization in equal and unequal cell divisions. Develop. Biol. 124, 9-22, 1987

28. Spudich, A. and J.A. Spudich. Actin in Triton-treated cortical preparations of unfertilized and fertilized sea urchin eggs. J. Cell Biol. 82, 212-226, 1979

29. Spudich, A., J.T. WrenN and N.K. Wessells. Unfertilized sea urchin eggs contain a discrete cortical shell of actin that is subdivided into two organizational states. Cell Motil. Cytoskel. 9, 85-96, 1988

30. Tinney, L.G. and L.A. JAfFe. Actin, microvilli, and the fertilization cone of sea urchin eggs. $J$. Cell Biol. 87, 771-782, 1980

31. Towbin, H., T. Staehelin and J. GoRdon. Electrophoretic transfer of proteins from polyacrylamide gels to nitrocellulose sheets: Procedure and some applications. Proc. Natl. Acad. Sci. USA 76, 4350-4354, 1979 
32. Tyler, J. and D. Braton. Rotary shadowing of extended molecules dried from glycerol. $J$. Ultrastruct. Res. 71, 95-102, 1980

33. Tyler, J.M., J.M. Anderson and D. Branton. Structural comparison of several actin-binding macromolecules. J. Cell Biol. 85, 489-495, 1980

34. VACQuire, V.D. Dynamic changes of the egg cortex. Develop. Biol. 84, 1-26, 1981

35. WANG, L.-L. and J.A. Spudich. A 45,000-mol-wt protein from unfertilized sea urchin eggs severs actin filaments in a calcium-dependent manner and increases the steady-state concentration of nonfilamentous actin. J. Cell Biol. 99, 844-851, 1984

36. Yonemura, S. and I. Mabuchi. Wave of cortical actin polymerization in the sea urchin egg. Cell Motil. Cytoskel. 7, 46-53, 1987

(Received for publication, March 9, 1989) 